\title{
Modern Housing Tranquillity in Malaysia from the Aspect of Thermal Comfort for Humid Hot Climate Zone
}

\author{
M.A. Baharum ${ }^{1}$, M. Surat ${ }^{2}$, N.M. Tawil ${ }^{3}$, A.I Che-Ani ${ }^{4}$ \\ ${ }^{1,2,3,4}$ Department of Architecture, Faculty of Engineering \& Built Environment, Universiti Kebangsaan \\ Malaysia, 436000 UKM Bangi, Selangor Darul Ehsan, Malaysia
}

\begin{abstract}
Development of housing is imperative to enhance the society's standard of living in this country. The factor of occupant comfort is the main element to indicate whether the housing is successful or not. In this writing, the thermal comfort discussed in only relating to the thermal comfort zone in Malaysia and the results from the study of the internal temperature of modern houses from previous researchers. Results by a few researchers found that modern houses are currently not reaching a good level of thermal comfort to live in and the designs are not capable to resolve the issue of discomfort in the internal environment of the houses in Malaysia. Therefore, thermal comfort is one of the important aspects of research in the development of modern housing because it plays a very important role in enhancing welfare, health and the quality of life or urban society.
\end{abstract}

\section{Introduction}

Fundamentally, a function of a house is to provide protection from extreme natural climate factors such as extreme heat, rain, cold and strong wind. The internal environment of houses must be safe, comfortable and could withstand the pressures of external climate such as sunlight, rain and wind. Therefore, the internal climate must be taken care so that the conditions of internal environment do not react like the external environment of the house. Hence, in order to reach a desired level of thermal comfort, it has to meet the physiological criteria of the human body. Therefore, the planning and design of buildings that meet the criteria of thermal comfort depend on the climate of a particular space in order to achieve comfort that can be felt by humans, for them to do their daily activities. Buildings must be designed to accommodate a variety of activities, to fulfil the physical and mental needs and to assist in maintaining the health of the occupants. This is because an unsuitable climate conditions can cause the mind and body strains, and also causes discomfort, efficiency loss and eventually affects human health.

\section{The Concept of Thermal Comfort}

Thermal comfort is a research aspect of the human's reaction towards climate effect on the human's body [1]. Climate is defined as climate for a particular area that is determined by the common weather condition and its elements that include sunlight, temperature, air humidity, wind and precipitation that affect the heat condition of a building. 
Human comfort also depends on several factors such as physical, psychological and sociology; these cannot be assessed separately and it relies on the combination of one or more of these factors. Comfortable heat is said to be a subjective quality that depends on different individuals, and the exact definition for it is quite hard to come up with. This level of comfort is actually different from one individual to another. Therefore, it is hard to create an environment that can satisfy all. Nevertheless, Fanger [2] stated that if $95 \%$ of the individuals is found to be satisfied with their thermal environment, then this condition can be said as optimum condition.

Besides that, comfortable heat can also be determined through environmental, physical and subjective factors. Environmental factor are elements such as air temperature, relative humidity, air movement and sunlight, while subjective factor depends on each individual themselves and their ability to adapt to the environmental condition. The determination of comfort was done empirically through measurement of the temperature of the research area, comfort zone provided by the researchers and through a theoretical method of observing people's perspective. It was through this theoretical method that the comfort scale was assigned to find out the comfort condition of a particular area.

Comfortable heat as a condition for humans to evaluate whether their environment is cold or hot and is a natural determining point for the avoidance of discomfort [3]. O'Callaghan [4] opines, it is a natural condition of the body to not needing an adjustment to maintain the balance of heat. However, according to American Society of Air Conditioning Engineering - ASHRAE. [5] generally most researchers agreed that thermal comfort refers to the state of mind or human's perception that indicates satisfaction or not, from their thermal environment.

Thermal comfort happens when the flow of heat in the human's thermal system is balanced with the body temperature, which is $37^{\circ} \mathrm{C}$. Human's body adds or reduces heat through the skin, by conduction, convection, radiation from the air and the surrounding objects. If there is no thermal comfort, for instance too warm from the surroundings or even cool compared to surrounding conditions of the body, this surrounding can affect health and humans need to strive to modify themselves to enable the micro climate atmosphere to be balanced with their body's physiology. The steps that can be taken are using cooling tools, air conditioners and fan.

Thermal comfort has been defined in the ISO 7730 standards as a state of mind in which human express the feel of satisfaction towards their thermal environment. This definition is accepted by many, but it is not easy to convert it into a physical parameter for the comfort determination. For example, two people in a different situation of environment might be comfortable with their environment, regardless of whether they are inside or outside their house. This means that the thermal comfort depends not only on one parameter such as air temperature, but also involves many other parameters.

The compiled definitions above indicate that thermal comfort is a situation in which individuals feel comfortable with the surrounding temperature, whether inside or outside the house without having to change any weather elements or comfort aid tool at that time. It is also associated with climate and non-climate factors, and will determine the balance between human body and its surroundings. At this level, one will be able to maintain the body's stability to quench the heat without perspiring.

\section{Comfort Zone}

On the other hand, comfort zone is the range of a comfort heat condition. In this range, a suitable balancing mechanism of human's body temperature is at a minimum level of activity. In this comfortable surrounding condition, the movement and feeling of human will reach their best level. In this zone, the body does not need to do any action to maintain heat balance. Table 1 below summarizes the results of the researches done for comfort range, for several parts of the world. 
Table 1: Range of comfort zone for a few parts of the world.

\begin{tabular}{llc}
\hline Research & Area & Range/Temperature \\
\hline Fanger & - & $20^{\circ} \mathrm{C}$ \\
Markham & United Kingdom & $15.6^{\circ} \mathrm{C}-24.5^{\circ} \mathrm{C}$ \\
Vernon \& Bedford & - & $13.2^{\circ} \mathrm{C}-23.2^{\circ} \mathrm{C}$ \\
Brooks & United Kingdom & $14.5^{\circ} \mathrm{C}-21.1^{\circ} \mathrm{C}$ \\
& United State of America & $20.6^{\circ} \mathrm{C}-26.7^{\circ} \mathrm{C}$ \\
& Warm humid climate & $23.4^{\circ} \mathrm{C}-29.5^{\circ} \mathrm{C}$ \\
Saini & Dry humid climate & $31.1^{\circ} \mathrm{C}-33.9^{\circ} \mathrm{C}$ \\
CIBSE Guide & Warm humid climate & $25.5^{\circ} \mathrm{C}-27^{\circ} \mathrm{C}$ \\
\hline
\end{tabular}

\section{Thermal Comfort in Malaysia}

A few studies were done in the country to determine the thermal comfort. The study before Independence was done by Webb and Ellis. Ellis [6] done research on Asian male and female individuals to describe the comfort condition for Malaysia and Singapore. The study also found that most individuals found it comfortable when the temperature condition is as Table 2.

Table 2: Thermal Comfort Zone for Malaysia and Singapura

\begin{tabular}{ccc}
\hline Dry-bulb temperature $\left({ }^{\circ} \mathrm{C}\right)$ & Wet-bulb temperature $\left({ }^{\circ} \mathrm{C}\right)$ & $\begin{array}{c}\text { Effective Temperature } \\
\left({ }^{\circ} \mathrm{C}\right)\end{array}$ \\
\hline $24.4-29.8$ & $22.8-26.7$ & $21.7-25.5$ \\
\hline
\end{tabular}

Webb's study [7] on climate in Malaysian houses found that the maximum comfort is at an effective temperature of between $26.7^{\circ} \mathrm{C}$ to $27.2^{\circ} \mathrm{C}$ and temperature range of between $26.1^{\circ} \mathrm{C}$ to $27.8^{\circ} \mathrm{C}$. When the change of temperature exceeds $2.0^{\circ} \mathrm{C}$ from the optimum level, the discomfort will then be experienced by individuals. Optimum condition is felt half an hour after midnight and at 7.30a.m. The Latest study by Abdul Malek [8] on the other hand suggested that the thermal comfort range of Malaysians is between $25.5^{\circ} \mathrm{C}$ to $28^{\circ} \mathrm{C}$.

Table 3: Temperature of Buildings' Design

\begin{tabular}{rll}
\hline Location & $\begin{array}{c}\text { Maximum exterior design } \\
\text { temperature }\end{array}$ & Interior design temperature \\
\hline \multirow{2}{*}{ Kuala Lumpur } & $35^{\circ} \mathrm{C}$ dry-bulb & $24^{\circ} \mathrm{C}$ \\
& $35^{\circ} \mathrm{C}$ dry-bulb & $50 \%$ relative humidity \\
\hline
\end{tabular}

For the purpose of buildings' design, the range of comfortable heat can be obtained from a few guides and studies made for hot and humid climate like Malaysia. Estimation method of the Chartered Institute of Building Services Engineers Grazie - CIBSE serves as a general guide to assess the comfortable condition of an area. To find out a suitable condition of an interior or exterior design, the temperature of the building's design must be known through weather studies such as temperature, relative humidity and rain, and this is then documented using a special monogram for selection of the interior design of a certain area. For Malaysia, Schedule 3 gives the representation of a suitable design temperature for the internal or external condition. Mahoney's schedule, a guidance schedule for climate based building's designers that found the most suitable comfortable limits for areas with annual mean temperature exceeding $20^{\circ} \mathrm{C}$ such as Malaysia, came up with a schedule as Table 4.

Table 4: Mahoney's Schedule for Malaysian Climate

\begin{tabular}{ll}
\hline Average relative humidity & $70-100 \%$ \\
Daytime comfort & $22^{\circ} \mathrm{C}-27^{\circ} \mathrm{C}$ \\
Night comfort & $17^{\circ} \mathrm{C}-21^{\circ} \mathrm{C}$ \\
\hline
\end{tabular}

Relative humidity on the other hand very much influences the thermal comfort in hot and humid area as it usually exceeds 80 percent. Therefore, in thermal measurement, this study will refer to the 
relative humidity that is recommended by the Chartered Institute of Building Services Eragineers Guide - CIBSE guide, which explains that in order to maintain a comfortable condition in a hot and humid climate, relative humidity must be within a range of $40 \%-70 \%$ for most of the application.

Wind speed inside the house is a factor not less important in the research of thermal comfort. Webb [7] found in his study that the discomfort situation during noon/midday and hot times can be reduced if the wind speed in the house can be increased by an average $0.5 \mathrm{~m} / \mathrm{s}-1.2 \mathrm{~m} / \mathrm{s}$. On the other hand, the suitable wind speed to achieve comfort level is between $0.10 \mathrm{~m} / \mathrm{s}$ to $0.40 \mathrm{~m} / \mathrm{s}$ during daytime and between $0.07 \mathrm{~m} / \mathrm{s}$ to $0.29 \mathrm{~m} / \mathrm{s}$ at night. However, O'Callaghan [4] stressed that the range of air speed of between $0.1 \mathrm{~m} / \mathrm{s}$ to $1.0 \mathrm{~m} / \mathrm{s}$ is enough to achieve the desired comfort inside a house. CIBSE guide on the other hand recommended that the range of between $0.1 \mathrm{~m} / \mathrm{s}-0.25 \mathrm{~m} / \mathrm{s}$ for the comfort of most people in tropical climate.

\section{Thermal Climate of Modern Housing In Malaysia}

Table 5 shows the study on thermal comfort that was done by Haryati Shafii [9] on a few neighbourhoods under the Kajang Municipal Council's purview that includes Section 1 and 2 of Bandar Baru Bangi, Kajang Utama, Bukit Mewah, and Taman Sentosa. This study involved temperature measurement at 70 houses that were chosen as samples using the Discomfort Index (DI) method and the results of the study indicated that the temperature inside the houses is between $23{ }^{\circ} \mathrm{C}$ $31{ }^{\circ} \mathrm{C}$ while the relative humidity obtained for all types of houses are high which is between $51 \%$ to $90 \%$. The bungalows are the most comfortable houses with the thermal conditions recorded at $23{ }^{\circ} \mathrm{C}$ $28{ }^{\circ} \mathrm{C}$ and relative humidity of $65 \%-70 \%$. Flats are the most uncomfortable with a thermal condition recorded at $24{ }^{\circ} \mathrm{C}-32{ }^{\circ} \mathrm{C}$ and relative humidity of $51 \%$ - 59\%. Nevertheless, as a whole, besides bungalows being in a normal condition in the morning, the residence of many people in the Kajang municipal was found to be uncomfortable.

Table 5: Inside air temperature, DI minimum dan maximum index, and relative humidity according to type of house

\begin{tabular}{lcccc}
\hline Type of house & $\begin{array}{l}\text { Inside air temperature } \\
\text { (morning till night) }\end{array}$ & $\begin{array}{l}\text { Minimum DI } \\
\text { Index }\end{array}$ & $\begin{array}{l}\text { Maximum DI } \\
\text { Index }\end{array}$ & $\begin{array}{l}\text { Relative } \\
\text { Humidity }\end{array}$ \\
\hline Bungalow & $23^{\circ} \mathrm{C}-28^{\circ} \mathrm{C}$ & $25.6^{\circ} \mathrm{C}$ & $30.4^{\circ} \mathrm{C}$ & $65^{\circ} \mathrm{C}-71 \%$ \\
One storey terrace & $25^{\circ} \mathrm{C}-30^{\circ} \mathrm{C}$ & $26.8^{\circ} \mathrm{C}$ & $31.6^{\circ} \mathrm{C}$ & $67^{\circ} \mathrm{C}-70 \%$ \\
Two storey terrace & $25^{\circ} \mathrm{C}-26.5^{\circ} \mathrm{C}$ & $25.4^{\circ} \mathrm{C}$ & $28.6^{\circ} \mathrm{C}$ & $88^{\circ} \mathrm{C}-90 \%$ \\
Apartments & $25.5^{\circ} \mathrm{C}-30.1^{\circ} \mathrm{C}$ & $26.6^{\circ} \mathrm{C}$ & $31^{\circ} \mathrm{C}$ & $70^{\circ} \mathrm{C}-75 \%$ \\
Flat & $24^{\circ} \mathrm{C}-32^{\circ} \mathrm{C}$ & $26^{\circ} \mathrm{C}$ & $30.4^{\circ} \mathrm{C}$ & $51^{\circ} \mathrm{C}-59 \%$ \\
\hline
\end{tabular}

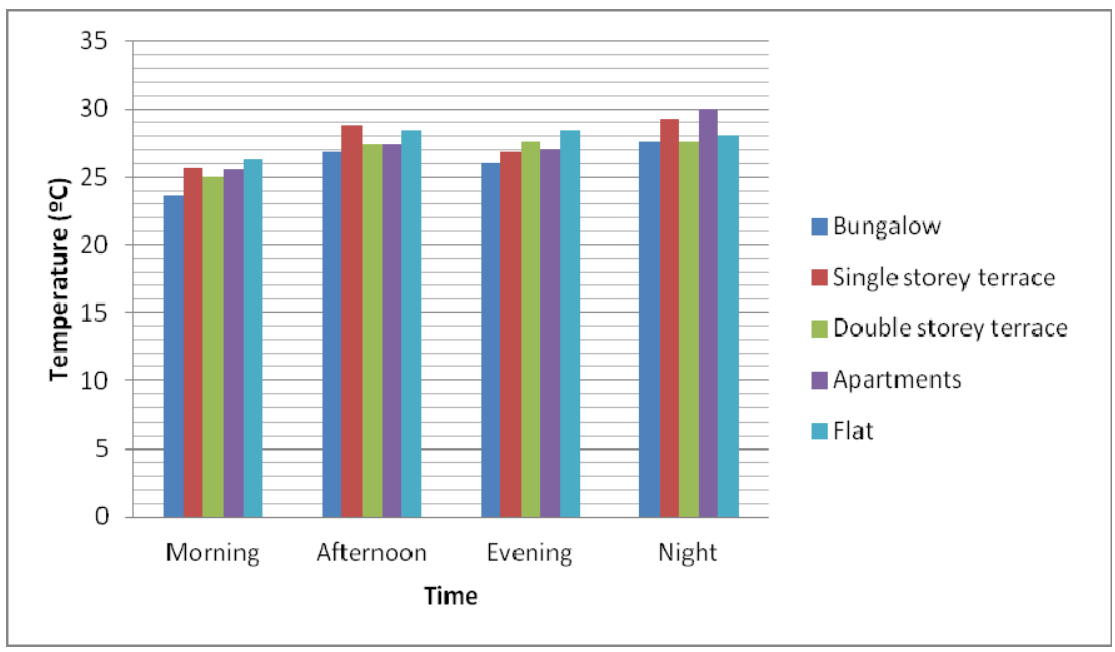

Figure 1: Thermal comfort - Times of DI according to type of houses 
Figure 1 shows the thermal comfort graph according to the times. From this graph bar, the reading of the minimum DI Index in the morning is the best compared with the other times, and is different according to the type of house being studied. Meanwhile, the DI Index in the evening and night for flats and double storey terrace houses are the most uncomfortable. Therefore, it can be summarized that there is no comfortable time that can be experienced by all types of houses, except for bungalows in the morning. It is also the most comfortable time at noon and at night. However, the apartments have the most uncomfortable conditions at night to be occupied, as compared to other houses. Double story terrace houses and bungalows have the best conditions compared to other type of houses. Thermal comfort study done by Mazlina Mansor [10] towards 4 modern housing in Bandar Tun Hussein Onn and Cheras Perdana which are single storey low cost houses, single storey medium cost houses, double storey medium cost houses and double storey semi-detached houses; they generally indicated temperature readings of between $27^{\circ} \mathrm{C}$ to $29^{\circ} \mathrm{C}$.

Table 6: Inside air temperature, minimum and maximum DI index and relative humidity according to type of houses

\begin{tabular}{ccccc}
\hline Station & $\begin{array}{c}\text { Inside Air Temperature } \\
\left({ }^{\circ} \mathrm{C}\right)\end{array}$ & $\begin{array}{c}\text { Minimum DI } \\
\text { Index }\end{array}$ & $\begin{array}{c}\text { Maximum DI } \\
\text { Index }\end{array}$ & $\begin{array}{c}\text { Kelembapan } \\
\text { Bandingan }\end{array}$ \\
\hline 1 & $27^{\circ} \mathrm{C}-29.5^{\circ} \mathrm{C}$ & $24.3^{\circ} \mathrm{C}$ & $26^{\circ} \mathrm{C}$ & $51-65 \%$ \\
2 & $27^{\circ} \mathrm{C}-29^{\circ} \mathrm{C}$ & $24.3^{\circ} \mathrm{C}$ & $26^{\circ} \mathrm{C}$ & $51-66 \%$ \\
3 & $27^{\circ} \mathrm{C}-29^{\circ} \mathrm{C}$ & $24.4^{\circ} \mathrm{C}$ & $25.8^{\circ} \mathrm{C}$ & $57-65 \%$ \\
4 & $27^{\circ} \mathrm{C}-28 \mathrm{C}$ & $24^{\circ} \mathrm{C}$ & $24.8^{\circ} \mathrm{C}$ & $50-59 \%$ \\
\hline
\end{tabular}

Indication: Station 1: single storey low cost houses ; Station 2: single storey medium cost houses ; Station 3: double storey medium cost houses ; Station 4: double storey semi-detached houses

The results of the above study can summarize that there is no difference from the aspect of thermal comfort between single storey low cost houses and single storey medium cost houses. On the contrary, semi detached houses were found to be the most comfortable compared to other types of houses. The result of the study also found that there are differences between the comfort of the single storey type of houses and the comfort of the double storey type of houses. Nevertheless, it is also found that the thermal comfort of double storey medium cost houses is not much different from the thermal comfort of low cost houses and single storey medium cost houses, though the design characteristics have many similarities with double storey semi detached houses. It can be concluded here that both types of houses which are low cost and medium cost houses are not comfortable to be inhabited at certain times.

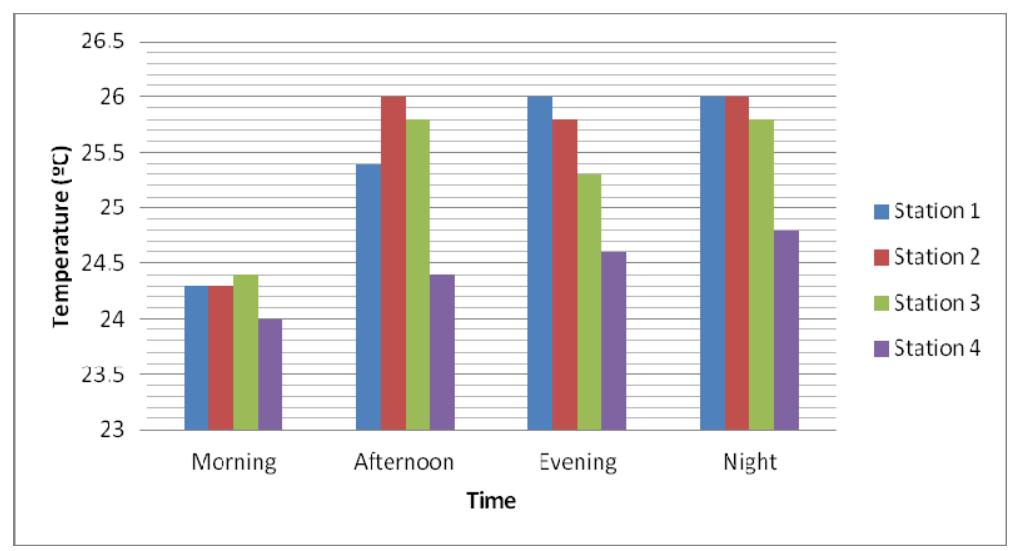

Figure 2: Thermal Comfort - DI times according to type of houses

Figure 2 above on the other hand shows the graph of thermal comfort according to time and it is found that comfort can be felt in the morning by all types of houses at the research stations while 
discomfort is felt at noon and night. The comparison of comfort times according to types of houses found that semi detached houses are better from the aspect of comfort compared to other houses. The comparison between low cost and medium cost houses found that comfortable condition can be felt in the morning for both types of houses while it is uncomfortable during noon, afternoon and night for both types of houses. These mean that there are no significant differences between the thermal comfort of low cost and medium cost houses from the time aspect, in which it is also found that medium cost houses are also uncomfortable to be inhabited at certain times, as what is being experienced in low cost houses.

Based on the studies of temperature measurement above, they clearly show that modern housing in Malaysia has not reached the level of comfort that is really tranquil to be occupied by people in Malaysia where an average modern house in Malaysia has a temperature range of between $23^{\circ} \mathrm{C}$ to $32^{\circ} \mathrm{C}$ when most individuals or occupants would only be comfortable when being in a temperature condition of $21.7^{\circ} \mathrm{C}-25.5^{\circ} \mathrm{C}$.

\section{Conclusion}

Thermal comfort is one of the important aspect of research in providing comfort and tranquillity to occupants. This has to be prioritized in the development of housing because I can increase the well being, health and subsequently the quality of life of urban society and altogether fulfils the definition of life quality that is aspired by the country. This aspiration includes self development, healthy life style and standard of living that exceed the basic needs of individuals. The research on the aspect of thermal comfort inside houses can assist to provide knowledge and disclose information for the planning and management of better housing development in the future. It becomes hope that this factor will receive more scrutiny in the planning and design of houses in the times to come. The approach through the design comprehension based on natural climate does not involve a lot of cost, but only through knowledge of its importance in planning of housing, can it provide the thermal comfort desired by society.

\section{References}

1. Zulkifli Hanafi (1999) Reka bentuk bangunan dalam iklim panas dan lembab di Malaysia.

2. Fanger PO (1970) Thermal comfort. Analysis and application in environmental engineering.

3. Markham SF (1947) Climate and the energy of nationas. Oxford Univ. Press., London.

4. O' Callaghan PW (1978) Building for energy conservation. Pengamon Press, Oxford.of Heating and Ventilating Engineers 20, 215 - 250.

5. ASHRAE (1977) Handbook of fundametals. American Society of heating and refrigeration

6. Ellis FP (1953) Thermal comfort in warm humid atmosphere: Observation on groups and environment. Sains Malaysiana 6 (1), 65 - 83

7. Webb CG (1952) On some observation of indoor climate in Malaya. Journal of the Institution

8. Abdul Malek Abdul Rahman (2000) Usaha-usaha mencapai keselesaan terma dalaman di air conditioning engineers.

9. Haryati Shafii (2012) Keselesaan terma rumah kediaman dan pengaruhnya terhadap kualiti

10. Mazlina Mansor (2003) Keselesaan termal dalam pembangunan perumahan bandar baru: New York. 